\title{
$16 S$ rRNA Sequence Analysis of Bacteria Present in Foaming Activated Sludge
}

\author{
Ankia M. Wagner and Eugene T. C Loete
}

\section{Introduction}

The performance of a sewage treatment plant depends upon the microbial community of the activated sludge (GRAY, 1990). The analyses of the microbial community in activated sludge is important for the understanding and possible control of separation problems in sewage treatment plants (SCHUPPLER et al., 1995). Foaming is one of the solid separation problems experienced in activated sludge systems that has compelled researchers to examine the biological component of the mixed liquor of activated sludge (BLACKALL and HUGENHOLTZ, 1999).

Foaming filamentous organisms are differentiated mainly using morphology (JENKINS et al., 1993, BLACKALL, 1994). Microorganisms identified in foams are Nocardia (now Gordona) amarae (KLATTE et al., 1994), N. rhodochrous, N. asteriodes, N. caviae, N. pinensis now called Skermania piniformis (CHUN et al., 1997), Streptomyces spp, Microthrix parvicella, Micromonospo-ra, Type 0675 and Rhodococcus (BLACKALL et al.,1989; GODDARD and FORSTER, 1987; LECHEVALIER and LECHEVALIER, 1974, 1975; LEMMER and KROPPENSTEDT, 1984; Pujol et al., 1991; SEVIOUR et al., 1990; SEzGIN and KARR, 1986; SEZGIN et al., 1988). Nostocoida limicola and Type 0041 can also cause foaming (GODDARD and ForSTER, 1987; WANNER and GRAU, 1989). Microorganism morphology is a poor descriptive attribute that can vary widely depending upon nutritional conditions. Because of their inadequate characterisation, most of the filamentous bacteria in activated sludge are not included in the widely used and generally accepted phenetic classifications (SEVIOUR and BLACKALL, 1999).

Employing molecular biological methods provide an alternative approach for the detection of microorganisms that are difficult to identify by conventional culture techniques or microscopy (BLACKALL, 1994). The analysis of $16 \mathrm{~S}$ rRNA genes, aided by using PCR to amplify target sequences in environmental samples, has enabled microbial ecologists to identify and characterise microorganisms in a natural community, like activated sludge, without prior cultivation (SCHUPPLER et al., 1995).

The taxonomic position of an organism can be determined by comparing the sequence with those of other bacteria (AMANN et al., 1995). Analysis of such data has helped to resolve the taxonomic position of some of the Eikelboom filaments (SEVIOUR and BLACKALL, 1999). Many of the filaments still remain to be characterised in this way and further extensive phenotypic characterisation is still needed before the organisms can be identified.

Molecular methods as mentioned above provide microbiologists with the tools to study the ecology and population dynamics of these filaments in activated sludge plants.

In this study foaming activated sludge from a water purification plant in Gauteng, South Africa was examined. The organisms in the foam were identified using molecular techniques and phylogenetically placed using the Clustal X software program.

\section{Materials and Methods}

\section{Sampling}

Activated sludge foam was collected from the aerobic zone of the Centurion Wastewater treatment plant in Gauteng, South Africa.

\section{Microorganisms present}

The filaments in the foam sample from Centurion WWTP occurred as Gram positive, irregularly coiled filaments that were found coiled in and around the floc. Filaments were $0.6-0.8 \mu \mathrm{m}$ in diameter and $100-400 \mu \mathrm{m}$ in length (not illustrated). No sheath or attached growth was present and no branching occurred. Cellular inclusions were common which gave a "beaded" appearance. According to Jenkins et al. (1993) these are characteristics true to "Microthrix parvicella".

\section{Sample preparation}

Volumes of $100 \mathrm{ml}$ foam were homogenised for $10 \mathrm{~min}$ using $70 \mathrm{~g}$ glass beads. The foam was pelleted by centrifugation for $10 \mathrm{~min}$ at $7000 \mathrm{rpm}$ in a Hermle $360 \mathrm{~K}$ centrifuge.

DNA extraction and purification (Modified from EHLERS, 1995)

After centrifugation, the supernatant was discarded. The pellet was resuspended in volumes of $40 \mathrm{ml}$ Sodium-Tris- 
EDTA buffer (STE, $\left.4{ }^{\circ} \mathrm{C}, \mathrm{pH} 8\right)(10 \mathrm{mM} \mathrm{NaCl}, 10 \mathrm{mM}$ Tris/HCl, $1 \mathrm{mM}$ EDTA) and $2 \mathrm{ml}$ lysosyme $(3 \mathrm{mg} / \mathrm{ml}$ of a freshly made $50 \mathrm{mg} / \mathrm{ml}$ stock solution). This was incubated on ice for $1 \mathrm{~h}$. SDS $(20 \%)$ and proteinase $\mathrm{K}(100 \mu \mathrm{g} / \mathrm{ml})$ were added to the cell suspension. The cell suspension was incubated overnight at $50{ }^{\circ} \mathrm{C}$ with slight agitation. Two gentle extractions with equal volumes phenol:chloroform/isoamylalcohol were carried out. The suspension was mixed for $30 \mathrm{~min}$ in a shake incubator at $100 \mathrm{rpm}$. Centrifugation was carried out at $7000 \mathrm{rpm}$ for 10 min to separate the organic and aqueous phases. The aqueous DNA-containing top layer was removed with a "wide bore pipet" without disturbing the white protein-rich interface. This step was repeated until there was no more protein visible. A final extraction step with equal volumes chloroform:isoamylalcohol was carried out by centrifugation for $10 \mathrm{~min}$ at $7000 \mathrm{rpm}$ in order to remove the residual phenol from the DNA suspension. The aqueous DNA phase was aliquoted into sterile microcentrifuge tubes, and adjusted to $0.3 \mathrm{M}$ sodium acetate (NaOAc) with a $3 \mathrm{M}$ NaOAc stock solution ( $\mathrm{pH}$ 5.2). Two volumes of cold $\left(-20^{\circ} \mathrm{C}\right)$ absolute ethanol was added on top of the aqueous layer and mixed. The DNA was precipitated overnight at $-20^{\circ} \mathrm{C}$. The solution was centrifuged at $10000 \mathrm{rpm}$ for 10 min at $0{ }^{\circ} \mathrm{C}$ to pellet the DNA. The supernatant was discarded and the tubes were inverted on towelpaper and left to air dry. The dried pellets were resuspended in 200-300 $\mu$ Tris-EDTA (TE) buffer. The DNA was concentrated. A volume of $1 \mathrm{ml}$ cold $\left(-20^{\circ} \mathrm{C}\right) 100 \%$ ethanol was added again and the salt precipitated for $2 \mathrm{~h}$ at $-20^{\circ} \mathrm{C}$. The DNA was pelleted again at $10000 \mathrm{rpm}$ for $10 \mathrm{~min}$. A wash step to desalt the pellets, with $70 \%$ ice cold $\left(-20^{\circ} \mathrm{C}\right)$ ethanol, was carried out and the pellets were left to air dry. TE buffer was added to the dried and desalted pellets. The purity and concentration of the DNA was determined with a CARY 1E UV-Visible spectrophotometer of Varian (Varian Australia) at $\mathrm{A}_{260}$ and $\mathrm{A}_{280}$.

\section{PCR amplification of 16S rDNA}

The 16S rRNA genes were amplified from total DNA using two universal bacterial primers, forward primer 27 and reverse primer 1492r (Table 1) (BLACKALL, 1994). The numbering of the primers is based on the Escherichia coli 16S rRNA gene. These primers amplify approximately 1400 to 1500 base pairs (bp) (BLACKALL, 1994). The primers were synthesised at ROCHE at a scale of 50 nmol. The $(50 \mu \mathrm{l})$ PCR mixture contained 25 pmol of each primer, $2.5 \mathrm{mM}$ of each dNTP (dATP, dGTP, dTTP, dCTP [Takara]), 10 X Reaction buffer (100 mM Tris/HCl, 500 $\mathrm{mM} \mathrm{KCl}, 15 \mathrm{mM} \mathrm{MgCl}$ ) (Takara), 0.5 unit of Taq DNA polymerase (Takara) and 10-50 ng of genomic bacterial DNA. The PCR was performed on a Perkin Elmer GeneAmp 2400 system. The DNA and $\mathrm{ddH}_{2} \mathrm{O}$ were subjected to a denaturation step of $98^{\circ} \mathrm{C}$ for 2 min followed by addition of the rest of the PCR mix and 30 cycles of $93{ }^{\circ} \mathrm{C}$ for 1 $\min , 48^{\circ} \mathrm{C}$ for $45 \mathrm{~s}, 72^{\circ} \mathrm{C}$ for $2 \mathrm{~min}$; a final re-annealing at $48{ }^{\circ} \mathrm{C}$ and extension at $72{ }^{\circ} \mathrm{C}$ for 10 min (BLACKALL, 1994). Following thermal cycling, the PCR products were visualised by agarose gel electrophoresis and UV illumination (SAMBROOK et al., 1989). Sizes of the amplicons were assessed by comparison with a 1 kb marker (Gibco, BRL) run in the agarose electrophoresis.

\section{PCR product purification}

The amplification mix was purified using the High Pure PCR Product Purification Kit following the standard protocol as supplied by the manufacturer (Boehringer Mannheim). The purification involved adding binding buffer to the PCR mix and centrifuging it through filter tubes. After this the unincorporated nucleotides were removed by adding wash buffer and centrifugation at $10000 \mathrm{rpm}$ for $2 \mathrm{~min}$. The PCR products were eluted using elution buffer and centrifugation.

\section{Clone library construction}

Clone libraries from purified PCR products were constructed using the PGemT-easy cloning kit following the standard protocol supplied by the manufacturer (Promega). Ligation of the PCR product to the vector was carried out using T4 DNA ligase, ligation buffer and a vector, all supplied by the manufacturer. The ligation was carried out at $4{ }^{\circ} \mathrm{C}$ overnight. Transformation was carried out using high efficiency competent cells and recombinant colonies were selected using blue/white colour screening.

\section{Purification of plasmids}

Each of the clones was resuspended in a volume of $5 \mathrm{ml}$ Luria Burtani Broth containing ampicillin $(10 \mathrm{~g} / \mathrm{L} \mathrm{NaCl}$, $10 \mathrm{~g} / \mathrm{L}$ Tryp-tone, $5 \mathrm{~g} / \mathrm{L}$ Yeast extract) and incubated at $37{ }^{\circ} \mathrm{C}$ overnight. The cells were centrifuged at $10000 \mathrm{rpm}$ for $1 \mathrm{~min}$ after which the supernatant was discarded. Each pellet was resuspended in $400 \mu \mathrm{l}$ lysis buffer $(50 \mathrm{mM}$ Glucose, $2 \mathrm{mM}$ Tris/ $\mathrm{HCl}, 10 \mathrm{mM}$ EDTA) and vortexed for 5-10 s. This was incubated at room temperature for 10 min. To this, $400 \mu \mathrm{l}$ freshly prepared $\mathrm{NaOH} / \mathrm{SDS}(0.2 \mathrm{M} \mathrm{NaOH}, 20 \%$ SDS $)$ was added and mixed thoroughly but carefully. This was left on ice for $10 \mathrm{~min}$. Volumes of $300 \mu \mathrm{l}$ cold $\left(4{ }^{\circ} \mathrm{C}\right) 7.5 \mathrm{M} \mathrm{NH}_{4} \mathrm{OAc}(\mathrm{pH} 7.6)$ was added to each pellet and mixed thoroughly but carefully. This was incubated on ice for $10 \mathrm{~min}$ and afterwards centrifuged for $10 \mathrm{~min}$ at $10000 \mathrm{rpm}$ at room temperature. An aliquot of $1000 \mu \mathrm{l}$ of the supernatant was collected in a new microcentrifuge tube and $650 \mu \mathrm{l}$ isopropanol was added to this and mixed. The mixture was left at room temperature for $10 \mathrm{~min}$ and then centrifuged for $10 \mathrm{~min}$ at $10000 \mathrm{rpm}$. The supernatant was discarded and $100 \mu \mathrm{l}$ of $2 \mathrm{M}$ $\mathrm{NH}_{4} \mathrm{OAc}$ ( $\mathrm{pH}$ 7.4) was added to the pellet and mixed thoroughly. This was left on ice for 10 min and then centrifuged for $10 \mathrm{~min}$ at $10000 \mathrm{rpm}$ at room temperature. The supernatant was collected and to this $110 \mu \mathrm{l}$ isopropanol was added. This was left at room temperature for $10 \mathrm{~min}$. The suspension was centrifuged at 10000 $\mathrm{rpm}$ for $10 \mathrm{~min}$ at room temperature and the supernatant discarded afterwards. The pellet was washed with $1 \mathrm{ml} 70 \%$ ethanol and then dried in the desiccator. Afterwards the pellet was dissolved in $25 \mu \mathrm{l} \mathrm{dH}_{2} \mathrm{O}$. The purified plasmids were screened for the correct sized insert using restriction enzyme digestion with EcoR1 for $1 \mathrm{~h}$ at $37^{\circ} \mathrm{C}$, and agarose gel electrophoresis. 
Fig. 1. Phylogenetic relationships of 25 bacterial clones (in bold), isolated from activated sludge foam, to other bacteria. The sequences were edited to $715 \mathrm{bp}$ and aligned using the CLUSTAL X software. The tree was reconstructed using the neighbour-joining algorithm. The Genbank accession numbers of the sequences are given in parenthesis. The bar indicates a $5 \%$ sequence divergence. $A .=A q u a b a c-$ terium; Bac. $=$ Bacteroides; $\mathrm{C} .=$ Cellulomonas; $\mathrm{Cap} .=\mathrm{Capnocytophaga;} \mathrm{Ch} .=$ Chryseobacterium; $C y .=$ Cytophaga; $D .=$ Dietzia; $E=$ Empedobacter; $F=$ Flavobacterium; Fx. = Flexibacter; H. = Haliscomenobacter; $J .=$ Janibacter; $L$. = Leptothrix; $M_{1}=$ Microthrix; $N_{1}=$ Nocardia $;$ Noc.$=$ Nocardiodes $;$ Nos $=$ Nostocoida $; O=$ Ornithobacterium; $R=$ Rhodococcus; $S$. = Sphingobacterium, $S m .=$ Sphingomonas; $S p h .=$ Sphaerotilus; $T=$ Terrabacter; $T s_{s}=$ Tetrasphaera $T s u .=$ Tsukamurella $;$ Unid. $=$ Unidenti fied; $\mathbf{W} .=$ Weeksella .

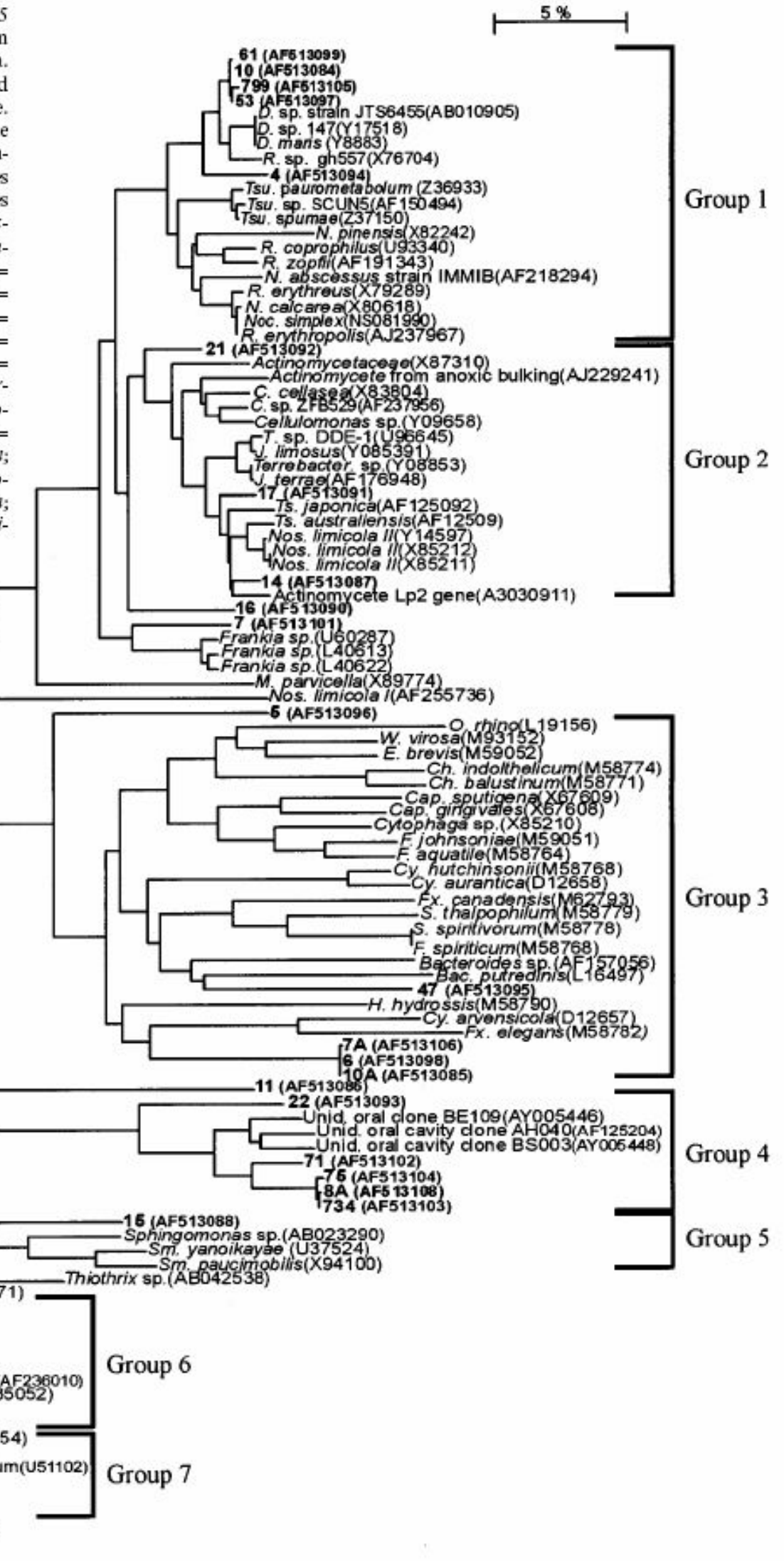




\section{Amplification of 16S rRDNA}

PCR's were performed on the recombinant clones using the vector primers SP6 and T7 (Table 1) to amplify the insert. The PCR mix consisted of 40 pmol of each primer, $2.5 \mathrm{mM}$ of dNTPs, 10X Reaction buffer (Takara), 0.5 U of Taq DNA poly-merase (Takara), 10-50 ng of genomic DNA and ddH2O to make up the volume of the reaction to $25 \mu$ l. The PCR products were purified using the High Pure PCR Product Purification Kit (Boehringer Mannheim). The protocol for the kit was followed. Products were visualised with ultra-violet illumination after agarose gel electrophoresis (SAMBROOK et al., 1989).

\section{Sequencing}

Sequencing of PCR amplified 16S rDNA was carried out using the ABI PRISM dye terminator cycle-sequencing ready-reaction kit (Perkin Elmer) and an ABI Prism 377 sequencer, according to the manufacturers protocol. The sequencing mix $-4 \mu \mathrm{l}$ Terminator ready reaction Mix, $50 \mathrm{ng}$ PCR product, $1.6 \mathrm{pmol}$ primer - was placed in the thermal cycler. The thermocycling protocol employed was one cycle of $96^{\circ} \mathrm{C}$ for $5 \mathrm{~s}$, and 25 cycles of denaturation at $96^{\circ} \mathrm{C}$; reannealing at $50^{\circ} \mathrm{C}$ for $5 \mathrm{~s}$ and extention at $60^{\circ} \mathrm{C}$ for $4 \mathrm{~min}$. The vector primers SP6 and T7 (PROMEGA) was used as end primers and the internal primers used were reverse primer ii, forward primer iv and the 530 forward primer (ROCHE) (Table 1). The excess dye terminators were removed from the reaction mixture by adding a mixture of $50 \mu \mathrm{l}$ of $100 \%$ ethanol and $2 \mu \mathrm{l} 3 \mathrm{M}$ sodium acetate $(\mathrm{pH} 5.2)$ to the sequencing reaction. This mixture was left on ice for $20 \mathrm{~min}$, after which it was centrifuged at $10000 \mathrm{rpm}$ for $20 \mathrm{~min}$ at $4{ }^{\circ} \mathrm{C}$. The supernatant was tipped off, and $250 \mu 170 \%$ ethanol was added, and tipped off again. The pellet was gently flicked and the tube centrifuged for $2 \mathrm{~min}$ at $10000 \mathrm{rpm}$. The excess fluid was carefully dried with a tissue, and the products vacuum dried (ca. 10 $\mathrm{min}$ ). For analysis, the purified products were resuspended in $3.5 \mu \mathrm{l}$ Blue dextran/EDTA loading buffer (PE Applied biosystems), denatured for 2 min at $90^{\circ} \mathrm{C}$ and loaded onto the ABI Prism model 377 DNA sequencer gel.

\section{Phylogenetic analysis}

The sequences obtained were trimmed of uncomparative data so that only from nucleotides 28-1491 were aligned and compared. Sequences were compiled using the Sequence Navigator software package (Applied Biosystems) and compared to available databases by the use of the Basic Local Alignment Search Tool (BLAST) (ALTSCHUL et al., 1997 ) to determine approximate phylogenetic affiliations. The compiled sequences were aligned using the Clustal X software program (THOMPSON et al., 1997). The sequences determined in this study were phylogenetically placed by comparative analysis ( 715 nucleotides) with $16 \mathrm{~S}$ rDNA sequences of various other bacteria including members of the Cytophaga-Flavobacter-Bacteroides group (Table 2). Sequences (from the BLAST search) with the greatest similarity to the clone sequences were selected. These sequences were retrieved from the GenBank database. The phylogenetic tree (Fig. 1) was calculated using the neighbour-joining algorithm (SAITOU and NEI, 1987).

\section{Results and Discussion}

\section{Filaments in the foam sample}

The filamentous microorganism most frequently observed and with high abundance (approximately 75\%), in the Centurion WWTP foam sample was "Microthrix parvicella". Other filaments were so infrequently observed that no positive identification could be made and these occurred as rod shaped cells in chains and filaments that could resemble Type 0041 .

\section{PCR amplification of 16S rRNA genes}

The 16S rRNA genes of the bacteria in the foaming sample were amplified with the $27 \mathrm{f}$ and 1492r primers (Table 1), and PCR produced a single band of about $1500 \mathrm{bp}$.

\section{Clone library}

After screening 47 clones, 25 clones contained the correct sized insert and were submitted to automated cycle sequencing.

\section{Automated cycle sequencing}

The nucleotide sequences of the $16 \mathrm{~S}$ rRNA genes of the selected clones were determined with automated sequencing on the ABI PRISM 377 model and sequences of between 1400bp and 1464bp were obtained.

\section{Phylogeny of the clones}

The 25 clone sequences obtained (GenBank accession numbers AF513084 to AF513108) from the foam sample, were aligned and phylogenetically placed with sequences from various other bacteria that showed identity of 90$99 \%$ to the clone sequences in the BLAST search (Fig 1). Where similarity less than $90 \%$ were found the sequences with the greatest similarity to the clone sequence were used. The clone sequences were edited to a length of $1463 \mathrm{bp}$. After aligning these sequences to the sequences obtained from GenBank, all of the sequences were trimmed to 715 bp to accommodate shorter sequences from GenBank. 
The dendrogram indicated 7 genotypic clusters (Fig. 1).

In Group 1, clones 61, 10, 799, 53 and 4 showed similarities greater than 95\% with Dietzia maris which was

Table 1. Sequences of the primers used in amplification and sequencing reactions.

\begin{tabular}{lll}
\hline Name and Sequence & Sequence 5 ${ }^{\prime}-3^{\prime}$ & Reference \\
\hline 27 forward & GAGTTTGATCCTGGCTCAG & BLACKALL, 1994 \\
1492 reverse & TACGGYTACCTTGTTACGACTT & BLACKALL, 1994 \\
SP 6 & TTTAGGTGACACTATAGAATAC & PROMEGA \\
T 7 & TAATACGACTCACTATAGGCGA & PROMEGA \\
530 forward & GTGCCAGCMGCCGCGG & LANE, 1991 \\
Forward no. II & GTGTAGCGGTGAAATGCGTAG & KUNHERT et al., 1996 \\
Reverse no. VII & CTTGCGACCGTACTCCCCAGGC & KUNHERT et al., 1996 \\
\hline
\end{tabular}

reclassified from Rhodococcus maris by RAINEY et al. (1995). D. maris has been isolated as a dominant microbe from activated sludge foam (SEZGIN et al. 1988).

In Group 2 clones 14 and 17 grouped with Nostocoida limicola II often associated with foaming activated sludge (SEVIOUR and BlaCKALl, 1999). Clone 17 showed more than 95\% similarity to the Terrebacter and Janibacter spp. Clone 21 seemed to be similar to the Actinomycetaceae species within Group 2. Clone 16 grouped alone, but had less than 4\% sequence divergence from Group 2 that included Nostocoida limicola II, also a well known foam forming filamentous microorganism (SEVIOUR and BLACKALL, 1999).

Although clone 47 falls into group 3, which comprises members of the Cytophaga-Flavobacter-Bacteroides (CFB) group, it only had a 90\% similarity with Flavobacterium sp.(Fig. 1). Clones 7A, 6 and 10A had less than 90\% similarity to the CFB group.

Group 4 included a number of unidentified bacterial clones from oral cavities. Clones 71, 75, 8A and 734 formed a cluster with this group of clones. Clone 22 also showed greater than $91 \%$ similarity with these clones. One of the unidentified clones from an oral cavity (AH040) was resolved into the third subdivision of the candidate division TM7 (HugenHOLTZ et al., 2001). This subdivision includes bacterial clones from foaming activated sludge (HugENHOLTZ et al., 2001).

Although clone 15 showed similarities of $96 \%$ and more with the organisms in Group 5, when the sequence was compared with those of other bacteria, it also indicated a 97\% homology with members of Group 7 (Fig. 1).

Group 7 indicated that the sequences of clones 8,62 and 15A were more than $95 \%$ similar to that of a denitrifying Fe-oxidising bacterium as well as Aquabacterium aqua and Beta-proteobacterium B8 (Fig 1). Group 7 had less than $1 \%$ sequence divergence from Group 6 which involved the filamentous bacteria Eikelboom Type 1701 and Sphaerotilus natans strain IF9, both associated with activated sludge bulking and foaming.

Clone 5 did not fall into any of the groups in the dendogram (Fig. 1). However, a nucleotide sequence of approximately 440 nucleotides showed $97 \%$ similarity to members of group 1 i.e. Dietzia, Rhodococcus and Nocardia spp. that form part of the filamentous bacteria associated with activated sludge foam (SEVIOUR and BLACKALL, 1999).

Clone 11 was not closely associated to any of the groups of bacteria examined in the study (Fig. 1). This clone showed 88\% similarity to an uncultured bacterium SJA-68 (not indicated in Fig. 1).

Clone 7 had a $93 \%$ similarity with members of the genus Frankia (Fig. 1).

The sequences from the clones obtained indicate a wide variety of organisms present in the foam sample without prior cultivation of the bacteria present in the sample. Although only a small number of clones were se-quenced, the results indicated that some of the clones isolated did group with the filamentous organisms associated with foaming activated sludge.

"Microthrix parvicella" was not identified in the study and this is contrary to the fact that it was established by microscopy that " $M$. parvicella" was the dominant filamentous organism in this sample. The DNA extraction protocol might not have been efficient enough to break up all Gram-positive cells such as "M. parvicella". Another possible explanation for the discrepancy of not finding a $16 \mathrm{~S}$ rDNA sequence for " $M$. parvicella" could be that the primer set that was used in this study targeted a too narrow range of bacteria. Cloning can also introduce bias in that not all of the clones obtained are sequenced and in this way the organism expected could be missed. The fact that only a few (25) positive clones were obtained in this study could have contributed to "Microthrix parvicella" not being among those organisms identified from the sample.

The reason that no clear homology or no definite identification could be made in this study could be that the existing database could still be limited in terms of the sequences available for the filamentous organisms. Hence the importance of further studies like this to expand the database on the filamentous microorganism sequences. 


\section{References}

Altschul, S. F., Madden, T. L., Schäffer, A. A., Zhang, J., Zhang, Z., Miller, W. and LiPMAN, D. J. Gapped BlAST and PSI-BLAST: a new generation of protein database search programs. Nucleic Acids Res. 25, 3389-3402. www.ncbi.nlm.nih.gov/BLAST (1997).

AMANN, R. I., Ludwig, W., SCHLEIFER, K.-H..Phylogenetic identification and in situ detection of individual microbial cells without cultivation. Microbiol. Rev. 59. 143-169 (1995).

Blackall, L. L., Parlett, J. H., Hayward, A. C., Minnikin, D. E., Greenfield, P. F. and Harbers, A. E. Nocardia pinensis sp. nov., an actinomycete found in activated sludge foams in Australia. J. Gen. Microbiol. 135, 1547-1558 (1989).

BLACKALL, L. L. Molecular identification of activated sludge foaming bacteria. Water Sci. Technol. 29, 35-42 (1994).

Blackall, L. L., and Hugenholtz, P., Molecular biological techniques in activated sludge microbiology: a short review. IAWQ Activated sludge population dynamics newsletter. (1999)

Chun, J., Blackall, L. L., KANG, S.-O., HAH, Y. C. and Good-Fellow, M. A proposal to reclassify Nocardia pinensis Blackall et al. 1989 as Skermania piniformis gen nov., comb. nov. Int. J. System. Bact. 47, 127-131 (1997).

EhLERS, M. M.: The sensitivity of DNA reannealing kinetics for bacterial diversity determination. M.Sc. dissertation. University of Pretoria, South Africa. (1995).

GODDARD, A. J. and FORSTER, C. F. A further examination into the problem of stable foams in activated sludge plants. Microbios. 50, 29-42 (1987).

GRAY, N. F.: Activated sludge theory and practice. Oxford University Press 1990.

Hugenholtz, P., Tyson, G. W., WebB, R. I., WagneR, A. M. AND Blackall, L.. Investigation of candidate division TM7, a recently recognized major lineage of the bacterial domain with no known pure-culture representatives. Appl. Environ. Microbiol. 67, 411-419 (2001).

Jenkins, D., Richard, M. G. and DAIGGER, G. T.: Manual on the causes and control of activated sludge bulking and foaming. New York, Lewis publishers, 1993.

Klatte, S., Rainey, F. A. and Kroppenstedt, R. M. Transfer of Rhodococcus aichiensis Tsukamura 1982 and Nocardia amarae Lechevalier and Lechevalier 1974 to the Genus Gordona as Gordona aichiencis comb. nov. and Gordona amarae comb. nov. Int. J. Systematic Bact. 44, 769-773 (1994).

LeCheVAlieR, M. P. and LeCheVAliER, H. A. Nocardia amarae sp. nov. an actinomycete common in foaming activated sludge. Int. J. Syst. Bacteriol. 24, 278and288 (1974)

LeCHEVAlieR, M. P. and LeCheVALIER, H. A. 1975. Actinomycetes of sewage treatment plants. EPA Report no. 600/2and75/031.

LEMMER, H. and KROPPENSTEDT, R. M. Chemotaxonomy and physiology of some actinomycetes isolated from scumming activated sludge. Syst. Appl. Microbiol. 5, 124 (1984).

Pujol, R., Duchene, PH., SChiETRIte, S. and CANLER, J. P. Biological foams in activated sludge plants: Characterization and situation. Water Res. 25, 1399and1404 (1991).

Rainey, F. A., Burghardt, J., Klatte, S. and Stackebrandt, E. Polyphasic evidence for the transfer of Rhodococcus roseus to Rhodococcus rhodocrous. Int. J. Syst. Bacteriol. 45, 101-103 (1995).

SAITOU, N. and NEI, M. The neighbour-joining method: a new method for reconstructing phylogenetic trees. Mol. Biol Evol. 4, 406-425 (1987).

SAmBroOK, J., Fritsch, E. F. , MANiATIS, T.: Molecular cloning: A laboratory manual. Cold Spring Harbour, NY Cold Spring Harbour Laboratory 1989.

SCHUPPleR, M., MERTENS, F., SCHÖN, G. and GÖBEL U. B. Molecular characterization of nocardioform actinomycetes in activated sludge by 16S rRNA analysis. Microbiology. 141, 513-521 (1995).

Seviour, E. M., Williams, R. J., Seviour,R. J., Sodell, J. A. and LindREA, K. C. A survey of filamentous bacterial populations from foaming activated sludge plant in eastern states of Australia. Water Res. 24, 493-498 (1990).

SEVIOUR, R. J., BLACKALL, L. L.: The microbiology of activated sludge. London . UK, Kluwer Academic Press 1999.

SEZGIN, M. and KARR, P. R. Control of actinomycete scum on aeration basins and clarifiers. J. Water Polln. Control Fedn. 58, 972-977 (1986).

SEZGin, M., LECHEVALIER, M. P. and KARR, P. R. Isolation and identification of actinomycetes present in activated sludge scum. In: Proceedings of the international conference on water and wastewater microbiology, Newport Beach, CA, Feb 8-11, Vol 1. 1988.

Thompson, J. D., Gibson, T., Plewniak, F. , Jeanmougin, F. and Higgins, D. The CLUSTAL_X windows interface: Flexible strategies for multiple sequence alignment aided by quality analysis tools. Nucleic Acids Res. 25, 4876-4882 (1997).

WANNER, J. and GRAU, P. Identification of filamentous microorganisms from activated sludge: A compromise between wishes and possibilities. Water Res. 23, 883-891 (1989). 